\title{
PRODUKSI: KAJIAN TEKSTUAL DAN KONTEKSTUAL
}

\author{
Refky Fielnanda \\ Fakultas Ekonomi dan Bisnis Islam UIN STS Jambi \\ refkyfielnanda@uinjambi.ac.id \\ Rafidah \\ Fakultas Ekonomi dan Bisnis Islam UIN STS Jambi \\ rafidah_haris@yahoo.com
}

\begin{abstract}
Abstrak:
Dalam hadis Nabi menganjurkan agar manusia dalam berproduksi selalu mengembangkan sumber daya alam secara efisien, bahkan seandainya tidak mampu mengembangkannya maka dianjurkan bekerja sama dengan yang lain. Tulisan ini menjelaskan tentang produksi dalam kajian tekstual atau pun realitanya dalam kajian kontekstual. Dalam tulisan ini dijelaskan bahwa produksi tidak hanya menciptakan secara fisik sesuatu yang tidak ada menjadi ada, tetapi menjadikan sesuatu dari unsur-unsur lama yaitu alam menjadi bermanfaat. Dari binatang ternak misalnya, orang dapat mengambil kulitnya untuk dijadikan pakaian dan barang jadi lainnya, dari susu binatang ternak dapat diperas dijadikan minuman susu segar ataupun susu bubuk untuk bayi. Manusia harus mengoptimalkan pikiran dan keahliannya untuk mengembangkan sumber-sumber investasi dan jenisjenis usaha dalam menjalankan apa yang telah disyari’atkan.
\end{abstract}

Keyword: Produksi, Hadis, Sumber Daya Alam

\section{PENDAHULUAN}

Hadis adalah sumber hukum Islam yang kedua setelah Alquran. Selain sebagai sumber, hadis juga berfungsi sebagai penjelas dan penafsir Alquran. Berdasarkan hal tersebut, maka kajian tentang hadis memiliki kedudukan yang penting di dalam studi ilmu-ilmu sumber dalam Islam. Banyak hadis yang menjelaskan al-Qur'an yang dikenal dengan hadis tafsir dan dari hal itu banyak ulama tafsir menulis tafsirnya dengan menggunakan hadis sebagai sumber tafsir di antaranya dilakukan oleh al-Suyuti dalam karyanya al-Durar al-Mansur fi al-Tafsir alMa'sur. ${ }^{1}$

${ }^{1}$ Imam Jalal al-Din al-Suyuti, al-Durr al-Mansur fi Tafsir al-Ma'sur (Beirut: Da>r al-Kutub al-Ilmiyyah, 1990 
Antara al-Qur'an dan hadis sebagai sumber ajaran Islam terdapat perbedaan. Salah satu perbedaan yang cuup mendasar adalah terletak pada periwayatannya. AlQur'an diriwayatkan secara mutawatir sedangkan tidak semua hadis diriwayatkan secara mutawatir. ${ }^{2}$ Kecuali terhadap hadis mutawatir, terhadap hadis abad kritik tidak saja ditujukan kepada sanad tetapi juga terhadap matan. Oleh sebab itu, penelitian hadis diperlukan. ${ }^{3}$

Dalam hadis Nabi berikut menganjurkan agar manusia dalam berproduksi selalu mengembangkan sumber daya alam secara efisien, bahkan seandainya tidak mampu mengembangkannya maka dianjurkan bekerja sama dengan yang lain. Ibnu Majah mengatakan, Nabi bersabda "Barang siapa yang mempunyai tanah maka tanamilah, jika tidak mampu maka supaya ditanami oleh saudaranya"

Produksi dapat meningkatkan kesejahteraan manusia dimuka bumi. Dalam ilmu ekonomi modern, kesejahteraan ekonomi diukur dengan uang, sedangkan dalam Islam kesejahteraan ekonomi terdiri dari bertambahnya pendapatan yang diakibatkan oleh meningkatnya produksi dan keikutsertaan sejumlah orang dalam proses produksi. ${ }^{4}$

\section{KONSEP PRODUKSI}

Produksi dalam bahasa arab adalah al-intaaj dari akar kata nataja, tetapi dalam istilah fiqih lebih dikenal dengan kata tahsil, yaitu mengandung arti penghasilan atau menghasilkan sesuatu. Begitupun dengan Ibnu Khaldun, menggunakan kata tahsil untuk produksi ketika ia membahas pembagian spesialisasi tenaga kerja. ${ }^{5}$ Dalam kamus Bahasa Indonesia produksi berarti hasil atau penghasilan. ${ }^{6}$

Salah satu defenisi tentang produksi adalah aktivitas menciptakan manfaat dimasa kini dan mendatang. Disamping pengertian di atas,pengertian produksi juga merujuk kepada prosesnya yang mentransformasikan input menjadi output. Segala jenis input yang masuk dalam proses produksi untuk menghasilkan output produksi disebut faktor produksi.

Syuhudi Ismail, Hadis Nabi menurut Pembela Pengingkar dan Pemalsunya (Cet. I; Jakarta Gema Insani Press, 1995), hal. 92-108.

3 Syuhudi Ismail, Metode Penelitian Hadis Nabi (Cet. I; Jakarta: Bulan Bintang, 1992), hal. 7-21. lihat juga Syuhudi Ismail, Kaedah Kesabihan Sanad Hadis: Telah Kritis dan tinjauan dengan pendekatan Ilmu Sejarah (Cet, II; Jakarta: Bulan Bintang, 1995), hal. 85-118.

${ }^{4}$ Ilfi Nur Diana, Hadis-Hadis Ekonomi, (Malang: UIN Malang Press, 2008), hal. 38.

${ }^{5}$ Ibnu Khaldun, Muqaddimah, (Kairo: al-Maktabah,1930), hal. 35.

'Indrawan WS, Kamus Lengkap Bahasa Indonesia Masa Kini, (Jombang: Lintas Media,1999), hal. 239. 
Pemahaman produksi dalam Islam memiliki arti sebagai bentuk usaha keras dalam pengembangan faktor-faktor sumber produksi yang diperbolehkan. Hal ini sesuai dengan firman Allah SW'T dalam Qur'an surah Al-Maidah ayat 87. Islam menghargai seseorang yang mengolah bahan baku kemudian menyedekahkannya atau menjualnya sehingga manusia dapat memenuhi kebutuhan hidupnya atau untuk meningkatkan ekonomi untuk mencukupi kebutuhannya sendiri. Pekerjaan seseorang yang sesuai keterampilan yang dimiliki, dikategorikan sebagai produksi, begitupun kesibukan untuk mengolah sumber penghasilan juga dapat dikatakan produksi. $^{7}$

Produksi tidak hanya menciptakan secara fisik sesuatu yang tidak ada menjadi ada, tetapi menjadikan sesuatu dari unsur-unsur lama yaitu alam menjadi bermanfaat. Dari binatang ternak misalnya, orang dapat mengambil kulitnya untuk dijadikan pakaian dan barang jadi lainnya, dari susu binatang ternak dapat diperas dijadikan minuman susu segar ataupun susu bubuk untuk bayi. Manusia harus mengoptimalkan pikiran dan keahliannya untuk mengembangkan sumber-sumber investasi dan jenis-jenis usaha dala menjalankan apa yang telah disyari’atkan.

\section{REDAKSI HADIS DALAM KUTUB AL-SITTAH}

Hadis yang akan diteliti adalah berdasarkan kitab Sunan Ibnu Majah Nomor 2452. Setelah diadakan penelusuran dalam kitab tersebut maka didapatkan informasi bahwa hadis tersebut terletak pada Kitab Rubn dalam Bab al-muzara'ab bi al-tsulutsi wa al-rub'i. Kegiatan selanjutnya adalah pentakhrijan hadis. Upaya tersebut didukung dengan kitab al-Mu'jam. ${ }^{8}$ Dan didapatkan hasil bahwa yang menyamai redaksi dengan hadis yang diriwayatkan oleh Ibn Majah tersebut adalah Shahih Bukhari dan Sahih Muslim. Adapun haditsnya sebagai berikut:

${ }^{7}$ Abdul Husain, Ekonomi Islam,Prinsip,Dasar,Tujuan, (Yogyakarta: Magistra Insani Press, 2004), hal. 161.

${ }^{8}$ A.J. Wensick, al-Mu'jam al-Mufahras li Alfa $>$ z al-H\}adi $>$ s, juz V (Leiden: E.J. Brill, 1936), h. 500. 
1. Shahih Bukhari Kitab Al-Muzara'ah Bab Man Kaa Na Min Ash-Habi Al-Nabiyyi Saw No. 2340. ${ }^{9}$

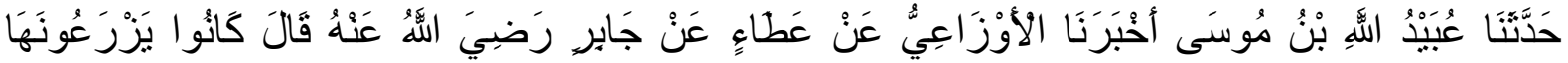

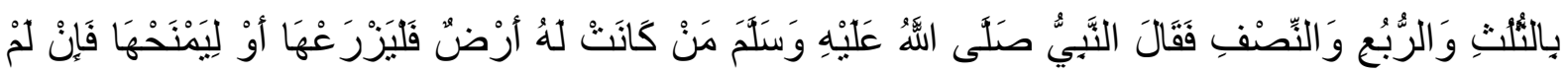

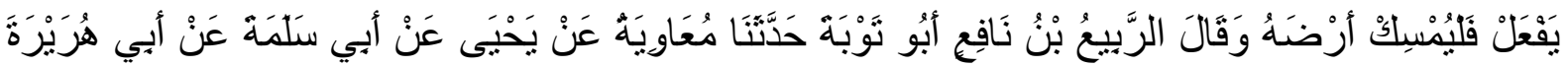

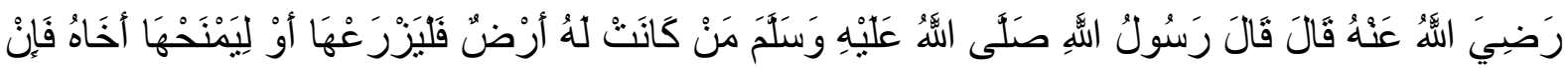

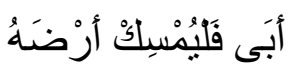

Artinya: Telah menceritakan kepada kami ['Ubaidullah bin Musa] telah mengabarkan kepada kami [Al Awza'iy] dari [Atha'] dari [Jabir radliallabu 'anbu] berkata: "Dabulu orang-orang mempraktekkan pemanfaatan tanah ladang dengan upah sepertiga, seperempat atau setengah maka Nabi shallallabu 'alaibi wasallam bersabda: "Siapa yang memiliki tanah ladang hendaklah dia garap untuk bercocok tanam atau dia bibabkan. Jika dia tidak lakukan maka hendaklah dia biarkan tanahnya". Dan berkata, [Ar-Rabi' bin Nafi' Abu Taubab] telah menceritakan kepada kami [Mu'awiyab] dari [Yabya] dari [Abu Salamab] dari [Abu Hurairah radliallabu 'anbu] berkata; Rasulullah shallallabu 'alaibi wasallam bersabda: "Siapa yang memiliki tanah ladang hendaklah dia garap untuk bercocok tanam atau dia berikan kepada saudaranya (untuk digarap). Jika dia tidak lakukan maka bendaklah dia biarkan tanabnya".

2. Shahih Bukhari Bab Hibah Wa Fadhliha Wa Al-Takhridh Alaiha Bab Fadhli AlManihah No. $2632^{10}$

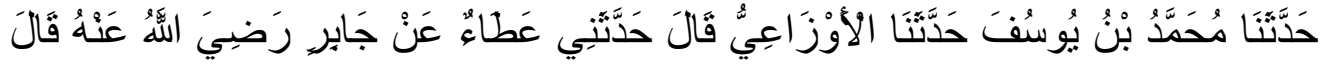

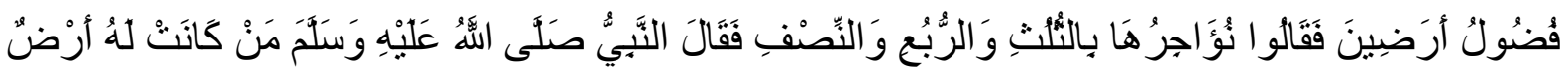

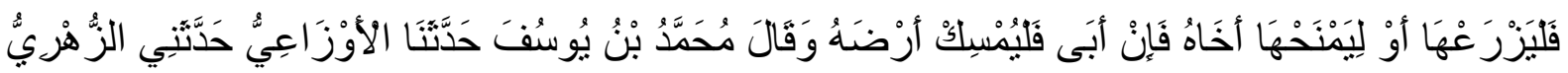

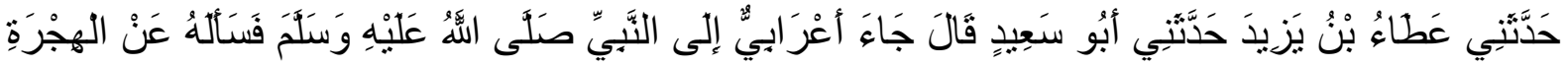




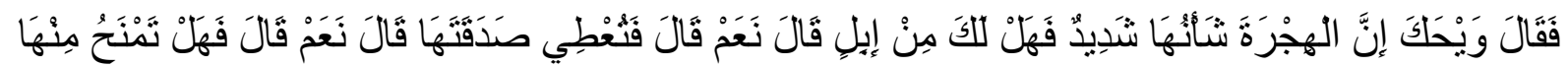

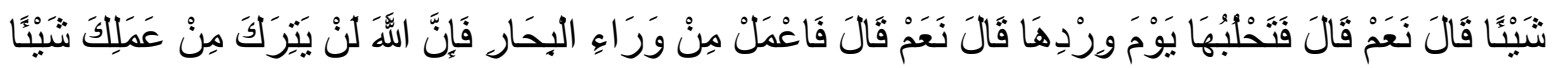

Artinya: Telah menceritakan kepada kami [Mubammad bin Yusuf] telah menceritakan kepada kami [Al Awra'iy] berkata, telah menceritakan kepadaku [Atho'] dari [Jabir radliallahu 'anbu] berkata; Ada orang-orang dari kami yang memiliki banyak lahan tanah. Mereka berkata: "Kami akan sewakan dengan pembagian sepertiga, seperempat dan atau setengah". Maka Nabi shallallahu 'alaibi wasallam bersabda: "Siapa yang memiliki lahan hendaklah dia tanami atau dia berikan kepada saudaranya untuk digarap. Jika dia tidak mau, hendaklah dia biarkan tanabnya". Dan Mujabid bin Yusuf berkata, telah menceritakan kepada kami Al Awza'iy telah menceritakan kepadaku $A z$ Zubriy telah menceritakan kapadaku 'Atho' bin Yazid telah menceritakan kapadaku Abu Sa'id berkata: "Datang seorang Baduy kepada Nabi shallallahu 'alaibi wasallam lalu bertanya tentang bijrah. Maka Beliau menjawab: "Bagaimana kamu ini, sesunggubnya hijrah adalah perkara yang berat. Apakah kamu ada memiliki unta?" Dia menjawab: "Ya punya". Lalu Beliau bertanya: "Apakah kamu mengeluarkan zakatnya?" Dia menjawab: "Ya". Beliau bertanya lagi: "Apakah ada darinya yang kamu berikan (badiabkan)?" Dia menjawab: "Ya". Beliau bertanya lagi: "Apakah kamu memberinya susu saat kehausan?" Dia menjawab: "Ya". Maka Beliau bersabda: "Beramallah kamu dari seberang lautan karena Allah tidak akan mengurangi sedikitpun dari amalan kamu".

3. Shahih Muslim Kitab Al-Buyu' Bab Kira'a Al-Ardhi No. $1544^{11}$

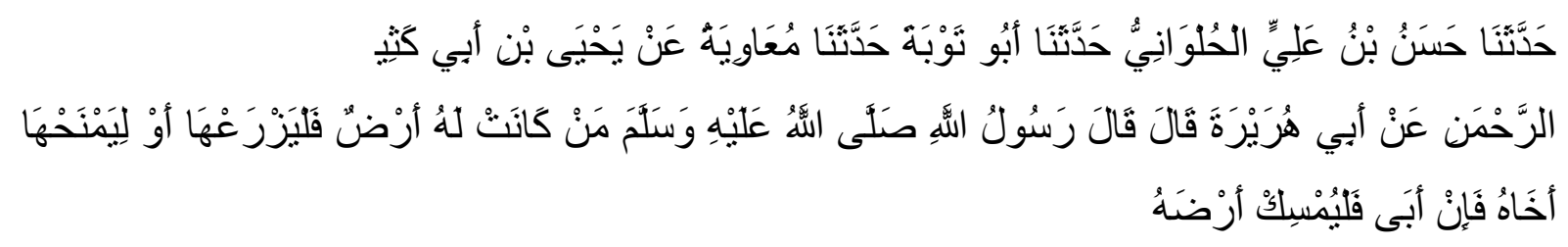

${ }^{11}$ Imam Muslim, Shahih Muslim, (Riyadh: Bait al-Afkar al-Dauliyyah, 1998), hal. 629. 
Artinya: Telah menceritakan kepada kami [Husain bin Ali Al Hulwani] telab menceritakan kepada kami [Abu Taubah] telab menceritakan kepada kami [Mu'awiyab] dari [Yabya bin Abi Katsair] dari [Abu Salamah bin Abdurrabman] dari [Abu Hurairab] dia berkata; Rasulullah Shallallu 'alaibi wa sallam bersabda: "Barangsiapa memiliki sebidang tanah, hendaklah ia menanaminya, atau memberikannya kepada saudaranya (supaya menanaminya), Namun jika ia tidak mau, hendaklah ia menjaganya".

4. Sunan Ibn Majah Kitab Al-Rubn Bab Al-Murara'ah Bi Al-Tsulutsi Wa Al-Rub'i No. $2452^{12}$

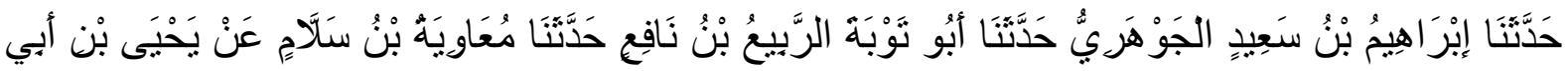

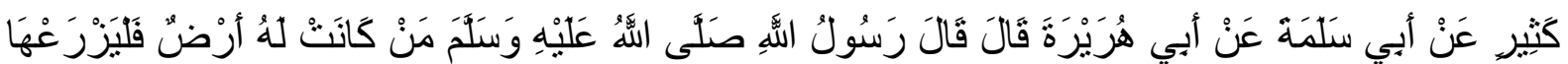

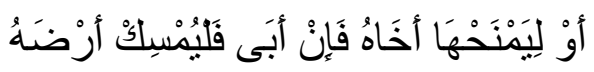

Artinya: Telah menceritakan kepada kami [Ibrahim bin Sa'id Al Jaubari] berkata, telah menceritakan kepada kami [Abu Taubah Ar Rabi' bin Nafi'] berkata, telah menceritakan kepada kami [Mu'awiyah bin Salam] dari [Yabya bin Abu Katsir] dari [Abu Salamah] dari [Abu Hurairab] ia berkata, "Rasulullab shallallabu 'alaibi wasallam bersabda: "Barangsiapa memiliki sebidang tanah bendaklah ia menanaminya atau ia berikan pengolahannya kepada saudaranya, namun jika menolak hendaklab ia tahan tanabnya."

لِيَنْنْهَ(hendaklah dia memberikan secara gratis). Maksudnya, diberikan untuk diambil manfaatnya secara gratis. Imam Muslim meriwayatkan melalui jalur

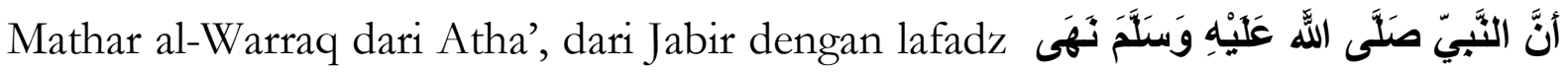
(Sesungguhnya Nabi SAW melarang menyewakan tanah). Pada jalur

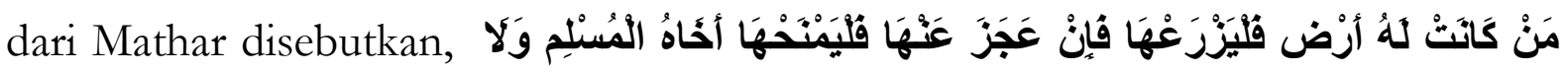
(Barang siapa memiliki lahan, maka hendaklah menanaminya. Apabila tidak 
mampu, maka hendaklah memberikannya kepada saudaranya sesama muslim, dan janganlah dia menyewakannya). riwayat al-Auza’i yang disebutkan Imam Bukhari menjelaskan maksud larangan ini, karena dalam riwayat itu disebutkan sebab larangan tersebut.

(a)abila tidak melakukannya, maka hendaklah dia menahan tanahnya). Yakni, jika tidak mau mengelolanya dan tidak mau memberikan kepada orang lain untuk dikelola secara gratis, maka hendaklah menahan dan tidak menyewakannya.

Dalam hal ini timbul kemusykilan bahwa menahan tanah tanpa dikelola berarti menyia-nyiakan manfaat tanah itu. Dalam hal ini termasuk menyia-nyiakn harta, sedangkan sikap seperti ini dilarang.

Kemusykilan ini dijawab dengan memahami bahwa yang dilarang adalah menyia-nyiakan harta itu sendiri atau manfaat yang ada gantinya. Sebab, jika tanah itu ditinggalkan tanpa dikelola, maka manfaatnya tidak terputus. Bahkan, akan tumbuh rerumputan dan kayu-kayu sehingga dapat dimanfaatkan sebagai tempat penggembalaan dan lain sebagainya.

Meskipun apa yang kami sebutkan tidak ada, tetapi membiarkan lahan tidak digarap tetap dapat menyuburkan lahar tersebut. Mungkin saja hasil yang diperoleh pada tahun ini dapat menutupi hasil ketika tanah itu dibiarkan tanpa digarap. ${ }^{13}$

\section{TAHQIQ HADITS}

Adapun kualitas hadis ini adalah shahih lighairih, hadis shahih yang tidak memenuhi syarat-syaratnya secara maksimal ${ }^{14}$. Hal berdasarkan hasil jarh wa ta'dhil dalam software mausu'ah hadis, yaitu:

\footnotetext{
13 Ibnu Hajar al-Asqalani, Fathul Bari (Penjelasan Kitab Shabih Bukhari) Jilid 13, terj. Amiruddin (Jakarta: Pustaka Azzam, ), hal. 272-273.

${ }^{14}$ M. 'Ajaj al-Khathib, Ushul al-Hadits Pokok-pokok Ilmu Hadits (Jakarta: Gaya Media Pratama, 1998), hal. 277.
} 
Hadits Pertama yang terdapat di dalam Shahih Bukhari Kitab Al-Muzara'ah Bab Man Kaa Na Min Ash-Habi Al-Nabiyyi Saw No. 2340.

\begin{tabular}{|c|c|}
\hline 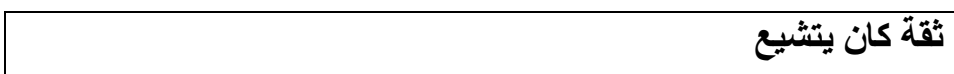 & عبيد الله بن موسى \\
\hline \multicolumn{2}{|l|}{ ثقة كثير الإرسال } \\
\hline & الربيع بن نافع أبو توبة \\
\hline & معاوية \\
\hline ثقة ثبت لكنه يدلس ويرسل & 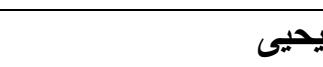 \\
\hline & ابو هريزة \\
\hline
\end{tabular}

Hadits Kedua yang terdapat di dalam Shahih Bukhari Bab Hibah Wa Fadhliha Wa Al-Takhridh Alaiha Bab Fadbli Al-Manibah No. 2632

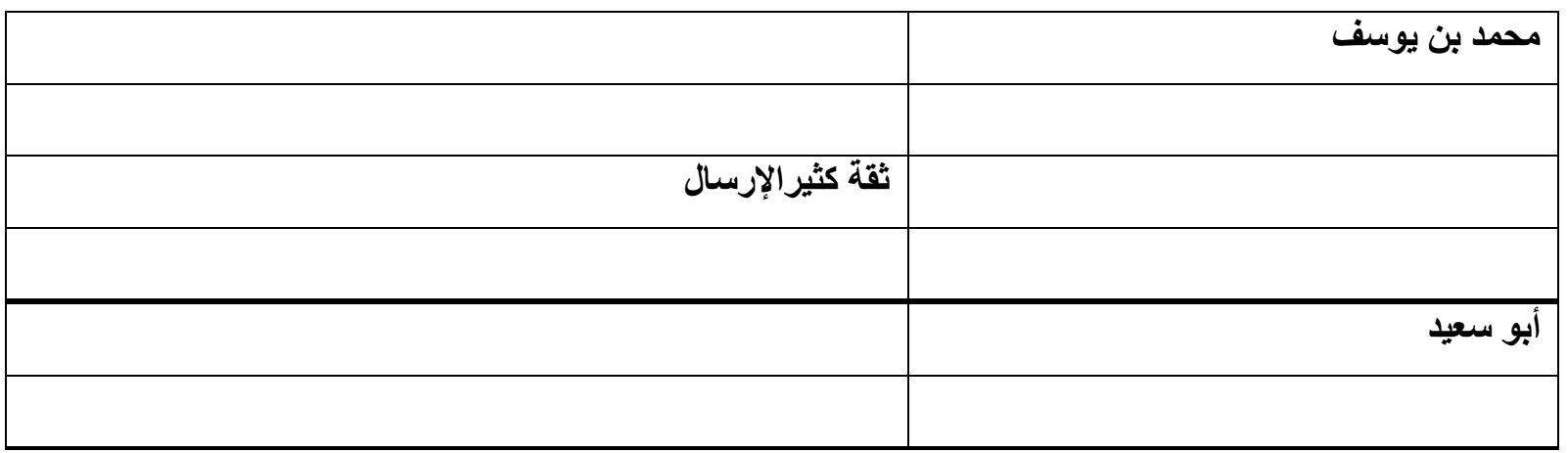

Hadits Ketiga yang terdapat di dalam Shahih Muslim Kitab Al-Buyu'Bab Kira'a Al-Ardhi No. 1544.

\begin{tabular}{|c|c|}
\hline ثقة كان يتثيع & \\
\hline & معاوية بن سلام \\
\hline ثقة ثبت لكنه يذلس ويرسل & يحيى بن أبي كثير \\
\hline & أبو هريرة \\
\hline
\end{tabular}


Hadits Keempat yang terdapat di dalam Sunan Ibn Majah Kitab Al-Rubn Bab Al-Muzara'ab Bi Al-Tsulutsi Wa Al-Rub'i No. 2452.

\begin{tabular}{|c|c|}
\hline & إبراهيم بن سعيد \\
\hline & معاوية بن سلام \\
\hline ثقة ثبت لكنه يالس ويرسل & يحيى بن أبي كثير \\
\hline & أبو هريرة \\
\hline
\end{tabular}

\section{KONTEKSTUALISASI HADITS}

Penggunaan tanah untuk pertanian telah dimulai sejak cara yang paling sederhana sampai dengan abad teknologi sekarang ini dengan mempergunakan mekanisasi pertanian yang modern. Hal ini didukung pula oleh kemajuan ilmu pengetahuan dan teknologi yang telah memungkinkan tanah memberikan hasil yang berlipat ganda, yaitu meningkatkan produksi panen dari tahun ke tahun. Hal ini bisa dicapai karena pengolahan tanah yang efektif dan efisien, seperti penggunaan pupuk, irigasi, mekanisasi alat-alat pertanian, penggunaan bibit unggul disertai obat-obat pebasmi hama, dan lain-lain. ${ }^{15}$

Di Indonesia sendiri di dalam pengolahan lahannya untuk memproduksi terutama gula sangat minim. Produksi gula di Indonesia hanya 1,68\% sedangkan gula yang dikonsumsi sebesar 2,79\% dari total konsumsi gula dunia Swasembada gula dapat dicapai antara lain dengan ekstensifikasi lahan tebu dan pengkajian potensi lahan di Indonesia untuk penanaman dan produksi tebu. Total area tebu di Indonesia saat ini sekitar 430.000 ha, masih kurang 420.000 ha untuk swasembada gula. Kekurangan ini secara teknis dapat diatasi karena potensi lahan dan karakteristik tanah yang cocok untuk ditanami tebu tersedia. Daerah yang sesuai berdasarkan kesesuaian lahan mencapai 33,80 juta ha, yang terdiri dari lahan sangat

${ }^{15}$ Khaelany HD, Islam, Kependudukan dan Lingkungan Hidup, (Jakarta: Rineka Cipta, 1996), hal. 90. 
sesuai 12,70 juta ha, moderta cocok dengan 6,30 juta ha, dan marjinal sesuai sekitar 14,80 juta ha. Penyebaran areal yang cocok untuk tebu adalah terluas di Kalimantan, Papua, Sumatera Selatan, Riau, Sumatera Utara, dan Lampung ${ }^{16}$.

Begitu juga dengan hutan produksi yang dimiliki oleh Indonesia, seharusnya bisa di berdayakan secara maksimal sehingga membantu perekonomin Indonesia sendiri. Berdasarkan data yang ada luas hutan produksi di Indonesia adalah 57,7 juta ha dan yang dikelola oleh pemegang ijin usaha pemanfaatan hasil hutan kayu seluas 37,58 juta ha serta sisanya seluas 20,12 juta ha tidak terdapat pengelolanya. Hal ini menunjukan bahwa hanya 65,13 \% dari luas hutan produksi yang dikelola sedangkan sisanya atau 34,87 \% dari luas hutan produksi tidak dikelola (Pusat Wilayah Pembentukan Kawasan Hutan, 2006). Pada kawasan yang tidak terdapat pengelolanya maka pemerintah dan pemerintah daerah harus mengambil peran dalam pembangunan hutan tersebut, hal ini telah diamanahkan pada UU No.41 Tahun 1999 tentang Kehutanan. Kabupaten Gowa adalah salah satu kabupaten yang terdapat di Sulawesi Selatan, memiliki luas wilayah 1.883,33 kilometer persegi atau sama dengan 3,01 persen dari luas wilayah Propinsi Sulawesi Selatan. Sebagian besar wilayah Kabupaten Gowa adalah dataran tinggi yaitu sekitar 72,26 persen. Dari total luas kabuaten Gowa, 35,30 persen adalah daerah yang memiliki kemiringan lereng di atas 40 persen. Luas penggunaan lahan kering di Kabupaten Gowa mencapai 153.965 ha dan diantaranya terdapat 43,04 persen adalah hutan (Kabupaten Gowa dalam Angka, 2006). Besarnya persentase luas kawasan hutan dilahan kering kabupaten Gowa dapat diperkirakan akan mempunyai peranan yang cukup besar baik dari aspek ekologi, sosial maupun ekonomi. Untuk mengetahui seberapa besar peranan sumber dayahutan ini terhadap perekonomian dan kelestarian hutan itu sendiri, maka perlu dikaji peranan ini pada berbagai sektor ekonomi ${ }^{17}$.

${ }^{16}$ Memet Hakim, Potensi Sumber Daya Lahan Untuk Tanaman Tebu di Indonesia, Jurnal Agrikultura 2010 Vol. I, hal. 5-12.

17 Samsul Alam dan Hajawa, Peranan Sumber Daya Hutan Dalam Perekonomian dan Dampak Pemungutan Rente Hutan Terhadap Kelestarian Hutan Di Kabupaten Gowa, Jurnal Perennila, Vol. 3, hal. 60. 
Pemeliharaan dan perawatan adalah hal yang sangat penting dalam mengembangkan dan pelestarian segala hasil cipta dan pekerjaan manusia itu. Juga terhadap segala sumber daya yang memungkinkan ia mencipta dan bekerja. Selain itu, manusia senantiasa ingin hidup dalam keadaan tenteram lalu ia menjaga terpeliharanya tata tertib kehidupan dalam lingkungan rumah tangganya dan di pergaulan ramai di masyarakatnya. Hal yang demikian inilah yang diisyaratkan dalan ajaran Sunnah yang menegaskan bahwa kalian (manusia) adalah pemeliharaan (ra'in). Dan pemeliharaan itu haruslah memikul tanggungjawab (mas'ul). ${ }^{18}$

Dalam rangka menggali manfaat dari lingkungan, tidak boleh diabaikan pula upaya untuk melestarikan lingkungan itu sendiri, artinya, hendaklah dijaga keseimbangan ekologi dan dihindari pencemaran serta diupayakan agar kekayaan alam itu dipergunakan sehemat mungkin. Bumi ini dikatakan bukanlah warisan dari nenek moyang kita, melainkan pinjaman dari anak cucu kita. Selaku peminjam kita harus pandai dan adil, tidak ceroboh, supaya barang pinjaman itu dapat kita kembalikan sebagaimana aslinya, atau mungkin lebih baik lagi. ${ }^{19}$

Tujuan produksi adalah menciptakan kemaslahatan atau kesejahteraan individu dan kesejahteraan kolektif (sosial). Setiap muslim harus bekerja secara maksimal dan optimal,sehingga tidak hanya dapat mencukupi dirinya sendiri tetapi harus dapat mencukupi kebutuhan anak dan keluarganya. Hasil yang dimakan oleh dirinya sendiri dan keluarganya oleh Allah dihitung sebagai sedekah, sekalipun itu sebagai kewajiban. Ini menunjukan betapa mulianya harga sebuah produksi apalagi jika sampai mempekerjakan karyawan yang banyak sehingga mereka dapat menghidupi keluarganya.

Menurut Chapra tujuan produksi adalah memenuhi kebutuhan pokok setiap individu dan menjamin setiap orang mempunyai standard hidup manusiawi, terhormat dan sesuai dengan martabat manusia sebagai khalifah. Tidak

18 Ali Yafie, Menggagas Fiqih Sosial: Dari Soal Lingkungan Hidup, Asuransi hingga Ukhuwah, (Bandung: Mizan, 1994) hal. 139-140.

${ }^{19}$ Khaelany HD, Islam, Kependudukan dan Lingkungan Hidup...., hal. 96. 
terpenuhinya kebutuhan tersebut dapat menimbulkan masalah mendasar bagi manusia. Oleh sebab itu, setiap muslim juga harus berusaha meningkatkan pendapatan agar menjadi mustahiq yang dapat membantu kaum lemah melalui pembayaran zakat, infaq, sedeqah dan wakaf. ${ }^{20}$ Dengan keyakinan akan peran dan kepemilikan absolut dari Allah Rabb semesta alam, maka konsep produksi di dalam ekonomi Islam tidak semata-mata bermotif maksimalisasi keuntungan dunia, tetapi lebih penting mencapai maksimalisasi keuntungan akhirat. Ayat 77 surah alQashash mengingatkan manusia untuk mencari kesejahteraan akhirat tanpa melupakan urusan dunia. Artinya, urusan dunia merupakan sarana untuk memperoleh kesejahteraan akhirat. ${ }^{21}$

Pada prinsipnya Islam juga lebih menekankan berproduksi demi untuk memenuhi kebutuhan orang banyak, bukan hanya sekedar memenuhi segelintir orang yang memiliki uang, sehingga memiliki daya beli yang lebih baik. Karena itu bagi Islam produksi yang surplus dan berkembang baik secara kwantitatif maupun kwalitatif, tidak dengan sendirinya mengindikasikan kesejahteraan bagi masyarakat. Apalah arti produk yang menggunung jika hanya bisa didistribusikan untuk segelintir orang yang memiliki uang banyak. ${ }^{22}$

Dari ungkapan Nabi SAW dalam hadits diatas yang menganjurkan bagi pemilik tanah hendaklah menanami lahannya atau menyuruh saudaranya (orang lain) untuk menanaminya. Ungkapan ini mengandung pengertian agar manusia jangan membiarkan lingkungan (lahan yang dimiliki) tidak membawa manfaat baginya dan bagi kehidupan secara umum. Memanfaatkan lahan yang kita miliki dengan menanaminya dengan tumbuh-tumbuhan yang mendatangkan hasil yang berguna untuk kesejahteraan pemiliknya, maupun bagi kebutuhan konsumsi orang lain. Hal ini merupakan upaya menciptakan kesejahteraan hidup melalui kepedulian

\footnotetext{
${ }^{20}$ M.Umar Chapra, Islam dan Tantangan Ekonomi, alih bahasa Ikhwan Abidin Basri (Jakarta: Gema Insani Press, Tazkiah Institute, 2000), hal.12.

${ }_{21}$ Mustafa Edwin Nasution,dkk, Pengenalan Eksklusif Ekonomi Islam, Jakarta: Kencana Media Group, 2007), hal.104.

${ }^{22}$ Ibid, hal.107.
} 
terhadap lingkungan. Allah s.w.t. telah mengisyaratkan dalam Al-Qur'an supaya memanfaatkan segala yang Allah ciptakan di muka bumi ini. Isyarat tersebut seperti diungkapkan dalam firman-Nya:

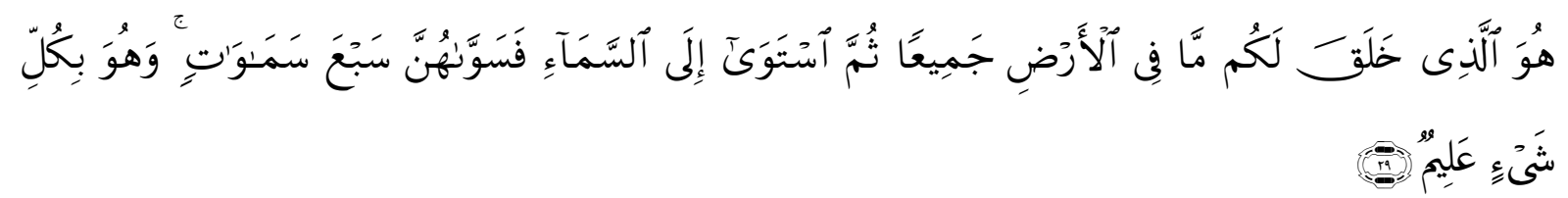

Artinya: Dia-lab Allah, yang menjadikan segala yang ada di bumi untuk kamu dan dia berkehendake (menciptakan) langit, lalu dijadikan-Nya tujub langit. dan dia Maha mengetahui segala sesuatu.

Dengan membiarkan tanah yang kosong mempunyai kemanfaatan lain, yaitu dengan menjaga ekosistem tanah tersebut, salah satunya menjaga unsur hara yang terkandung di dalamnya, sehingga kesuburan tanah tetap terjaga dan dapat digunakan untuk hal pertanian pada periode berikutnya.

Al-Qur'an dan Hadits Rasulullah SAW memberikan arahan mengenai prinsip-prinsip produksi sebagai berikut ${ }^{23}$ :

1. Tugas manusia dimuka bumi sebagai khalifah Allah adalah memakmurkan bumi dengan ilmu dan amalnya.

2. Islam selalu mendorong kemajuan di bidang produksi. Menurut Yusuf Qardhawi, islam membuka lebar penggunaan metode ilmiah yang didasarkan pada penelitian, eksperimen, dan perhitungan. Akan tetapi Islam tidak membenarkan penuhanan terhadap hasil karya ilmu pengetahuan dalam arti melepaskan dirinya dari Al-Qur'an dan Hadits.

3. Teknik produksi diserahkan kepada keinginan dan kemampuan manusia. Nabi pernah bersabda: "Kalian lebih mngetahui urusan dunia kalian"

${ }^{23}$ Mustafa Edwin Nasution, dkk, Pengenalan Eksklusif Ekonomi Islam, Jakarta: Kencana Media Group,2007), hal. 104. 
4. Dalam berinovasi dan bereksperimen,pada prinsipnya agama Islam menyukai kemudahan, menghindari mudarat dan memaksimalkan manfaat.

\section{KESIMPULAN}

Kegiatan produksi merupakan mata rantai dari konsumsi dan distribusi. Kegiatan produksilah yang menghasikan barang dan jasa, kemudian dikonsumsi oleh para konsumen. Tanpa produksi maka kegiatan ekonomi akan berhenti, begitu pula sebaliknya. Untuk mengahasilkan barang dan jasa kegiatan produksi melibatkan banyak faktor produksi. Beberapa implikasi mendasar bagi kegiatan produksi dan perekonomian secara keseluruhan, antara lain: Seluruh kegiatan produksi terikat pada tataran nilai moral dan teknikal yang Islami, kegiatan produksi harus memperhatikan aspek sosial-kemasyarakatan, permasalahan ekonomi muncul bukan saja karena kelangkaan tetapi lebih kompleks. Maka Hadits Jabir bin Abdullah RA ini merupakan larangan menelantarkan lahan, karena hal ini termasuk perbuatan yang tidak bermanfaat. Dalam menelantarkan lahan, Rasulullah SAW menyarankan untuk memanfaatkan dan mengupah orang lain untuk mengelolahnya. 


\section{DAFTAR PUSTAKA}

Abdul Husain, Ekonomi Islam,Prinsip,Dasar,Tujuan, Yogyakarta: Magistra Insani Press, 2004.

A.J. Wensick, al-Mu'jam al-Mufahras li Alfaz, al-Hadis, juz V Leiden: E.J. Brill, 1936. 'Ajaj al-Khathib, Ushul al-Hadits Pokok-pokok Ilmu Hadits Jakarta: Gaya Media Pratama, 1998.

Ali Yafie, Menggagas Fiqih Sosial: Dari Soal Lingkungan Hidup, Asuransi hingga Ukhuwah Bandung: Mizan, 1994

Ibnu Hajar al-Asqalani, Fathul Bari (Penjelasan Kitab Shahih Bukhari) Jilid 13, terj. Amiruddin Jakarta: Pustaka Azzam.

Ibnu Khaldun, Muqaddimah, Kairo: al-Maktabah,1930.

Ibnu Majah, Sunan Ibnu Majah, juz II Kairo: Mustafa al-Bab al-Hubla wa Auladuh, t.th

Ilfi Nur Diana, Hadis-Hadis Ekonomi, Malang: UIN Malang Press, 2008.

Imam Bukhari, Shahih Bukhari, Riyadh: Bait al-Afkar al-Dauliyyah, 1998.

Imam Jalal al-Din al-Suyuti, al-Durr al-Mansur fi Tafsir al-Ma'sur Beirut: Dar alKutub al-Ilmiyyah, 1990 M./1411 H.

Imam Muslim, Shahih Muslim, Riyadh: Bait al-Afkar al-Dauliyyah, 1998.

Indrawan WS, Kamus Lengkap Bahasa Indonesia Masa Kini, Jombang: Lintas Media,1999.

Khaelany HD, Islam, Kependudukan dan Lingkungan Hidup, Jakarta: Rineka Cipta, 1996.

Memet Hakim, Potensi Sumber Daya Lahan Untuk Tanaman Tebu di Indonesia, Jurnal Agrikultura 2010 Vol. I.

Mustafa Edwin Nasution, dkk, Pengenalan Eksklusif Ekonomi Islam, Jakarta: Kencana Media Group, 2007.

Samsul Alam dan Hajawa, Peranan Sumber Daya Hutan Dalam Perekonomian dan

Dampak Pemungutan Rente Hutan Terhadap Kelestarian Hutan Di Kabupaten Gowa, Jurnal Perennila, Vol. 3. 
Syuhudi Ismail, Hadis Nabi menurut Pembela Pengingkar dan Pemalsunya Cet. I; Jakarta Gema Insani Press, 1995. , Metode Penelitian Hadis Nabi (Cet. I; Jakarta: Bulan Bintang, 1992. Kaedah Kesabihan Sanad Hadis: Telah Kritis dan tinjauan dengan pendekatan Ilmu Sejarah Cet, II; Jakarta: Bulan Bintang, 1995.

Umar Chapra, Islam dan Tantangan Ekonomi, alih bahasa Ikhwan Abidin Basri Jakarta: Gema Insani Press, Tazkiah Institute, 2000. 